\title{
ЕКСПЕРИМЕНТАЛЬНЕ ДОСЛІДЖЕННЯ ЗАЛИШКОВИХ НАПРУЖЕНЬ ПОВЕРХНЕВИХ ШАРІВ ПРИ ТОНКОМУ АБРАЗИВНОМУ ШЛІФУВАНН КОМПОЗИТНИХ ПІДШИПНИКІВ КОВЗАННЯ ПОЛІГРАФІЧНИХ МАШИН
}

( А. П. Гавриш, д.т.н., професор, П. О. Киричок, д.т.н., професор, Т. А. Роїк, д.т.н., професор, Ю. Ю. Віцюк, к.т.н., А. В. Шевчук, д.т.н., професор, НТУУ “КПІ», Київ, Україна

В статье приведены результаты экспериментальных исследований влияния тонкого абразивного шлифования на величину, знак и глубину распространения остаточных напряжений. Установлены основные закономерности формирования остаточных напряжений, в частности, влияние материала абразива и зернистости абразивного круга на уровень значений и глубину залегания остаточных напряжений в поверхностных слоях подшипников скольжения полиграфических машин, изготовленных из новых высоколегированных и износостойких композиционных сплавов.

In an article the experimental researches of fine abrasive grinding influence for value, sign and depth of residual stresses have been presented. There were determined the main regularities of residual stresses formation in particular an influence of abrasive material and abrasive disc' graininess for value and depth of residual stresses in the surface layers of slider bearings manufactured from new high-alloyed wear-resistant composite materials for printing machines.

\section{Постановка проблеми}

Вимоги до деталей тертя, які працюють в умовах інтенсивного зношування, постійно зростають. Це обумовлює необхідність створення та удосконалення існуючих технологій виготовлення деталей такого типу, включаючи синтез нових видів матеріалів та розробку фінішних операцій технологічного процесу надтонкої абразивної обробки робочих поверхонь тертя із забезпеченням відповідних високих вимог до якості оброблення (мінімальних значень пара- метрів шорсткості поверхонь $\mathrm{Ra}$, мінімальних спотворень, знаку та значень залишкових напружень, дефектів тонкого поверхневого шару, глибини залягання наклепу, ступеню деформації металу у зоні зрізання стружки поодиноким абразивним зерном).

Ці якості формують умови придатності поверхні оброблення для забезпечення високих функціональних вимог експлуатації, зокрема, суттєвого підвищення термінів служби машин та механізмів друкарської техніки. 
На жаль, наразі не всі з наведених питань достатньо досліджені, оскільки нові композиційні сплави (на основі цінних шліфувальних відходів інструментальних сталей), які працюють у жорстких умовах експлуатації, лише нещодавно були створені і почали застосовуватись у промисловості [1-5]. Деякі параметри (шорсткість поверхні, характеристики наклепу), які суттєво впливають на зносостійкість та довговічність друкарської техніки (особливо підшипників ковзання високошвидкісних поліграфічних машин) та котрі формуються на етапах тонкої фінішної абразивної обробки нещодавно були всебічно досліджені авторами цієї статті і набули рівня рекомендацій для промисловців [5-8].

Проте виявлення залежності залишкових напружень, а саме, їх рівня, знаку (стиску чи розтягування) та глибини залягання у тонкому поверхневому шарі тертя від режимів абразивної обробки, матеріалу абразивного зерна, розміру зерна (його зернистості) до цього часу не проведено. Це не дозволяє оптимізувати режими різання при тонкому абразивному обробленні і ускладнює задачі з розробки технологічних процесів для виробників поліграфічної техніки.

Адже, відомо, що на параметри зносостійкості поверхонь тертя суттєво впливають не тільки параметри шорсткості $\mathrm{R}_{\mathrm{a}}$, a i, що не менш важливо, фізичні властивості тонкого шару поверхонь оброблення. Ці властивості (з точки зору загальної теорії шліфування) забезпечують- ся при обробці взаємодією силового та температурного полів на ріжучому лезі абразивного зерна шліфувального інструменту [6-9].

Таким чином, експериментальне дослідження залишкових напружень (з урахуванням попередньо отриманих теоретичних моделей їх формування [10] при тонкому абразивному шліфуванні нових композитних матеріалів на основі цінної вторинної сировини - шліфувальних відходів сталей 86Х6НФТ та 4ХМНФС), є актуальним питанням, що має наукове та практичне значення.

\section{Мета роботи}

Виконання експериментального дослідження залишкових напружень у поверхневому шарі оброблення при тонкому абразивному шліфуванні поверхонь підшипників ковзання, що виготовлені 3 нових композитних сплавів на основі шліфувальних відходів інструментальних сталей 86Х6НФТ та 4ХМНФС 3 домішками твердого мастила $\mathrm{CaF}_{2}$, та встановлення впливу зернистості шліфувального кругу (розміру зерен абразиву) та матеріалу зерна інструменту на залишкові напруження у тонкому поверхневому шарі оброблення.

\section{Результати виконаних досліджень}

Дослідження залишкових напружень виконувалось згідно 3 методикою, наведеною у роботах [5-9], при цьому постійно брались до уваги результати теоретичного дослідження формування залишкових напру- 
жень, які були виконані авторами і опубліковані у роботі [10].

Згідно до сучасного уявлення щодо формування залишкових напружень у поверхневому шарі деталей при механічній обробці взаємодіє два протилежних фактори - силовий і тепловий вплив інструменту на виріб.

Пластична деформація від нормальних сил різання веде до зміцнення поверхневого шару i появі стискуючих напружень, а високі температури у зоні різання викликають локальні термопластичні деформації і, відповідно, появу залишкових напружень розтягу.

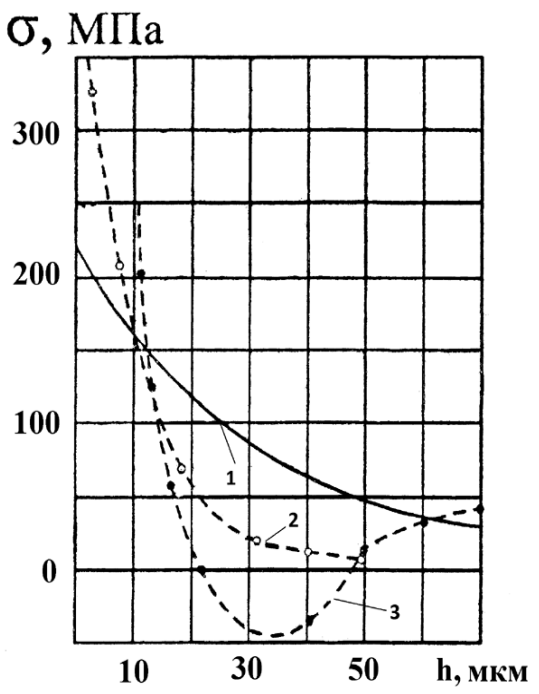

Рис. 1. Вплив зернистості абразивних кругів з карбіду кремнію зеленого (63С) та матеріалу, зв'язки абразиву керамічної (К), гліфталевої (Гл) на розподіл залишкових напружень поверхневого шару при тонкому шліфуванні композиційного сплаву 86Х6НФТ+5\% $\mathrm{CaF}_{2}: 1-$ круг

6325СМ2К5; 2 - круг 63С6СМ2Гл; 3 - круг 63СМ14СМ2Гл
Залишкові напруження, що виникають при абразивній обробці деталей, суттєво впливають на глибину залягання наклепу, а, отже, на параметри інтенсивності зношування поверхні.

Розрахунок рівня залишкових напружень виконувався згідно методики, наведеній у роботах [9, 10]. При цьому, значення силових і температурних параметрів обробки $\left(\mathrm{P}_{\mathrm{z}}, \mathrm{P}_{\mathrm{y}}, \mathrm{P}_{\mathrm{x}}\right.$, Т) стосовно конкретних режимів оброблення, встановлювались із сукупності експериментальних значень, отриманих раніше авторами при вивченні закономірностей утворення наклепу матеріалів [6, 8].

На рис. 1 представлено розподіл залишкових напружень за глибиною поверхневого шару. Глибина залягання максимальних напружень розтягу не перевищує 5-8 мкм.

Як відомо [7], при тонкому шліфуванні дрібнозернистими кругами відбувається зниження температур у зоні контакту абразивного зерна з поверхнею оброблення до 100-200 C і превалююче значення має силова дія шліфувального кругу. В результаті у поверхневому шарі сплаву повинні формуватися залишкові напруження стиску. Сaме це підтвердили виконані експериментальні дослідження залишкових напружень.

Слід зауважити, що враховуючи попередньо отримані закономірності формування шорсткості поверхонь [5], миттєвих контактних температур та складових сил різання [6, 7] у зоні оброблення, значень параметрів наклепу, в результаті яких було доведено, що най- 
кращі параметри обробки забезпечують абразиви на основі карбіду кремнію зеленого, при дослідженні залишкових напружень застосовувались тільки круги на основі карбіду кремнію зеленого (63C) та надтонкі режими різання [5, 6].

Аналіз графіків, наведених на рис. 1, показує, що на залишкові напруження поверхневого шару суттєво впливають розмір зерна абразиву (зернистість) та матеріал зв'язки кругу.

У цілому, при зменшенні зернистості абразивного інструменту при тонкому шліфуванні нових композитних сплавів типу шліф - відходи сталі 86X6HФТ+5\% $\mathrm{CaF}_{2}$ утворюються значні за величиною стискуючі напруження, глибина залягання яких сягає позначок 40-45 мкм, тобто силовий фактор стає домінуючим. При цьому чітко прослідковується зменшення рівня залишкових напружень зі зменшенням зернистості шліфувального інструменту.

Орієнтовний розрахунок залишкових напружень у поверхневому шарі матеріалу шліф відходи сталі 86Х6НФТ+ $+5 \% \mathrm{CaF}_{2}$ при обробці абразивами зернистістю 100 мкм ( $\left.\mathrm{T}=600^{\circ} \mathrm{C}\right)$ показав, що максимальне значення напружень розтягу складає $253 \mathrm{MПа,} \mathrm{тобто}$ порядок величин напружень розтягу, отриманих експериментально (200 МПа), практично однаковий.

У процесі тонкого абразивного шліфування деталей 3 нових композитних сплавів абразивами з зернистістю 100 мкм дія теплового фактору змен- шується і глибина залягання напружень розтягу знижується 3 35-40 до 30 мкм. При зменшенні діаметру абразивного зерна до 10-14 мкм у поверхневому шарі утворюються напруження стиску, глибина залягання яких сягає 10 мкм, тобто силовий фактор стає превалюючим.

При обробці абразивами зернистістю 10 мкм значення питомого навантаження на зерно $\mathrm{P}_{\text {уз }}$ знижується, при цьому робота пластичної деформації одиничного зерна зменшується і знижується величина залишкових напружень стиску (на 25-35 \%), а глибина їх залягання зменшується у 2-4 рази порівняно $з$ їх значеннями, отриманими при обробці кругами з більшим діаметром зерен.

Таким чином, мінімальна величина і глибина залягання залишкових напружень стиску можуть бути забезпечені застосуванням більш дрібнозернистих абразивів.

Глибина залягання максимальних значень напружень стиску і їх величина, отримані шляхом розрахунків [10], добре узгоджується 3 експериментальними даними, що свідчить про достовірність отриманих даних.

Дослідження залишкових напружень при тонкій абразивній обробці деталей з нового композитного сплаву на основі шліфувальних відходів сталі 4XМНФС+5\% $\mathrm{CaF}_{2}$ показало, що глибина залягання максимальних значень напружень розтягу не перевищує 5-8 мкм.

Це можна визначити за графіком, що наведений на рис. 2. 


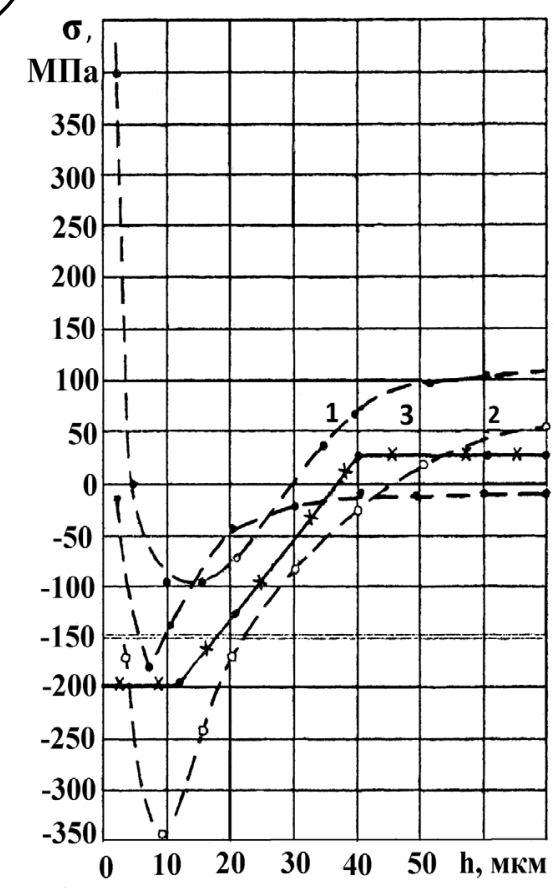

Рис. 2. Розподіл залишкових напружень за глибиною поверхнево-

го шару композитного сплаву 4ХМНФС+5\% $\mathrm{CaF}_{2}: 1$ - шліфування абразивами 63С10СМ2Гл; 2 - шліфування абразивом 63СМ14СМ2Гл; 3 - розрахункові дані

В цілому зазначимо, що при подальшому зменшенні діаметру абразивного зерна (при зберіганні швидкостей обробки у межах 25-30 м/с) значення складової сили різання $\mathrm{P}_{\mathrm{y}}$ зменшується, при цьому робота пластичної деформації одиничного абразивного зерна зменшується і знижується величина залишкових напружень стиску. 3 цього слідує практичний висновок, що застосування дрібнозернистих абразивів на гліфталевій зв'язці сприяє вирівнюванню значень товщини одиничного зрізу $\alpha_{z}$ і також обумовлює зменшення значень максималь- них залишкових напружень стиску ( на 25-30 \%) та глибини ї залягання порівняно з їх значеннями, отриманими при обробці досліджуваних матеріалів інструментами з крупними зернами.

\section{Висновки}

Узагальнюючи комплекс виконаних досліджень, необхідно зробити важливі як наукові, так і практичні висновки:

1. Доведено, що залишкові напруження у тонких поверхневих шарах при тонкому абразивному шліфуванні високолегованих композитних матеріалів на основі утилізованих сталевих відходів суттєво залежать від технологічних факторів оброблення.

2. Найбільший вплив на залишкові напруження чинять матеріал зерна абразивного інструменту, його зернистість та вид матеріалу зв'язки шліфувального кругу.

3. Показано, що експериментальні та розрахункові значення залишкових напружень співпадають, що свідчить про достовірність одержаних даних, а це, в свою чергу, дозволяє проектувати технологічні процеси абразивного оброблення деталей тертя, виготовлених з нових композиційних матеріалів, створених для жорстких умов експлуатації з відходів інструментального виробництва.

4. Розроблені практичні рекомендації для технологів заводів поліграфічного машинобудування, які забезпечують виконання відповідних вимог до поверхонь тертя деталей друкарської техніки. Забезпечення вимог якості до поверхонь оброблення 
досягається використанням для технологічних процесів тонкого абразивного шліфування абразивних інструментів на основі карбіду кремнію зеленого (63С), дрібнозернистого складу (зернистість 10-20 мкм) та застосування еластичної гліфталевої зв'язки при формуванні шліфувальних кругів.

1. Патент України № 60522, МПК С22С33/02 (2006.01). Підшипниковий композиційний матеріал на основі інструментальної сталі / Роїк Т. А, Гавриш А. П., Киричок П. О., Гавриш О. А., Віцюк Ю. Ю., Мельник О. О., опубл. 25.06.2011, Бюл. № 12. 2. Патент України № 30377 МПК (2006), С22С33/02 Порошковий антифрикційний матеріал на основі швидкорізальної сталі / Т. А. Роїк, А. П. Гавриш, В. В. Холявко, Б. П. Зора, опубл. 25.02.08, Бюл. № 4. 3. Гавриш А. П. Нові технології фінішного оброблення композиційних підшипників ковзання для жорстких умов експлуатації / А. П. Гавриш, О. О. Мельник, Т. А. Роїк, М. Г. Аскеров, О. А. Гавриш : Монографія. - К. : НТУУ «КПІ», 2012. - 196 с. 4. Роїк Т. А. Принципи одержання композиційних зносостійких матеріалів на основі відходів інструментального виробництва / Т. А. Роїк, А. П. Гавриш, П. О. Киричок, Ю. Ю. Віцюк, О. О. Мельник, В. В. Холявко // Междунар. сб. науч. трудов «Прогрессивные технологии и системы машиностроения». - Донецк : ДонНТУ, 2012. - Вып. 1, 2 (43). С. 261-265. 5. Гавриш А. П. Вплив абразивного інструменту на шорсткість поверхонь композитних підшипників поліграфічної техніки при тонкому шліфуванні / А. П. Гавриш, П. О. Киричок, Т. А. Роїк, Ю. Ю. Віцюк // Технологія і техніка друкарства. 2012. - № 3. - С. 65-77. 6. Гавриш А. П. Силове поле при тонкому абразивному шліфуванні деталей тертя з нових композиційних сплавів для друкарської техніки / А. П. Гавриш, П. О. Киричок, Т. А. Роїк, Ю. Ю. Віцюк // Междунар. сб. науч. трудов «Прогрессивные технологии и системы машиностроения». - Донецк : ДонНТУ, 2013. - Вып. 45. - С. 65-73. 7. Гавриш А. П. Дослідження температур при тонкому абразивному шліфуванні деталей з композитів на основі відходів інструментальних сталей / А. П. Гавриш, П. О. Киричок, Т. А. Роїк, Ю. Ю. Віцюк // Вісник Тернопільського технічного університету. 2013. - № 1. - С. 42-50. 8. Гавриш А. П. Аналіз параметрів якості поверхонь підшипників ковзання з композиційних сплавів для друкарських машин при абразивному шліфуванні / А. П. Гавриш, П. О. Киричок, Т. А. Роїк, Ю. Ю. Віцюк // Наукові Вісті НтуУ «КПІ». - 2013. - № 2. - С. 27-35. 9. Гавриш А. П. Алмазно-абразивна обробка магнітних матеріалів / А. П. Гавриш, П. П. Мельничук : Монографія. - Житомир : ЖДтУ, 2003. - 652 с. 10. Гавриш А. П. Формування залишкових напружень поверхневих шарів тертя композитних підшипників поліграфічних машин при тонкому абразивному шліфуванні / А. П. Гавриш, П. О. Киричок, Т. А. Роїк, Ю. Ю. Віцюк // Технологія і техніка друкарства. - 2012. - № 2. - С. 12-25.

1. Patent Ukrainy № 60522, MPK S22S33/02 (2006.01). Pidshypnykovyi kompozytsiinyi material na osnovi instrumentalnoi stali / Roik T. A, Havrysh A. P., Kyrychok P. O., Havrysh O. A., Vitsiuk Iu. Iu., Melnyk O. O., opubl. 25.06.2011, Biul. № 12. 2. Patent Ukrainy № 30377 MPK (2006), S22S33/02 Poroshkovyi antyfryktsiinyi material na osnovi shvydkorizalnoi stali / T. A. Roik, A. P. Havrysh, V. V. Kholiavko, B. P. Zora, opubl. 25.02.08, Biul. № 4. 3. Havrysh A. P. Novi tekhnolohii finishnoho obroblennia kompozytsiinykh pidshypnykiv kovzannia dlia zhorstkykh umov ekspluatatsii / A. P. Havrysh, O. O. Melnyk, T. A. Roik, M. H. Askerov, O. A. Havrysh : Monohrafiia. - K. : NTUU «KPI», 2012. - $196 \mathrm{~s}$. 4. Roik T. A. Pryntsypy oderzhannia kompozytsiinykh znosostiikykh materialiv na 
osnovi vidkhodiv instrumentalnoho vyrobnytstva / T. A. Roik, A. P. Havrysh, P. O. Kyrychok, lu. lu. Vitsiuk, O. O. Melnyk, V. V. Kholiavko // Mezhdunar. sb. nauch. trudov «Progressivnye tehnologii i sistemy mashinostroenija». - Doneck : DonNTU, 2012. - Vyp. 1, 2 (43). - S. 261-265. 5. Havrysh A. P. Vplyv abrazyvnoho instrumentu na shorstkist poverkhon kompozytnykh pidshypnykiv polihrafichnoi tekhniky pry tonkomu shlifuvanni / A. P. Havrysh, P. O. Kyrychok, T. A. Roik, lu. lu. Vitsiuk // Tekhnolohiia i tekhnika drukarstva. 2012. - № 3. S. 65-77. 6. Havrysh A. P. Sylove pole pry tonkomu abrazyvnomu shlifuvanni detalei tertia z novykh kompozytsiinykh splaviv dlia drukarskoi tekhniky / A. P. Havrysh, P. O. Kyrychok, T. A. Roik, lu. lu. Vitsiuk // Mezhdunar. sb. nauch. trudov «Progressivnye tehnologii i sistemy mashinostroenija». - Doneck : DonNTU, 2013. - Vyp. 45. - S. 65-73. 7. Havrysh A. P. Doslidzhennia temperatur pry tonkomu abrazyvnomu shlifuvanni detalei z kompozytiv na osnovi vidkhodiv instrumentalnykh stalei / A. P. Havrysh, P. O. Kyrychok, T. A. Roik, lu. Iu. Vitsiuk // Visnyk Ternopilskoho tekhnichnoho universytetu. - 2013. № 1. - S. 42-50. 8. Havrysh A. P. Analiz parametriv yakosti poverkhon pidshypnykiv kovzannia z kompozytsiinykh splaviv dlia drukarskykh mashyn pry abrazyvnomu shlifuvanni / A. P. Havrysh, P. O. Kyrychok, T. A. Roik, lu. lu. Vitsiuk // Naukovi Visti NTUU «KPI». - 2013. - № 2. - S. 27-35. 9. Havrysh A. P. Almazno-abrazyvna obrobka mahnitnykh materialiv / A. P. Havrysh, P. P. Melnychuk : Monohrafiia. - Zhytomyr : ZhDTU, 2003. - 652 s. 10. Havrysh A. P. Formuvannia zalyshkovykh napruzhen poverkhnevykh shariv tertia kompozytnykh pidshypnykiv polihrafichnykh mashyn pry tonkomu abrazyvnomu shlifuvanni / A. P. Havrysh, P. O. Kyrychok, T. A. Roik, lu. lu. Vitsiuk // Tekhnolohiia i tekhnika drukarstva. - 2012. - № 2. - S. 12-25.

Рецензент - В. Ф. Морфлюк, д.т.н., професор, НТУУ «КП।»

Надійшла до редакції 24.02.13 